\title{
Detecting pain severity with full cup test in painful diabetic peripheral neuropathy
}

\author{
Ağrılı diyabetik periferal nöropatide dolu bardak testi ile ağrı şiddetinin belirlenmesi
}

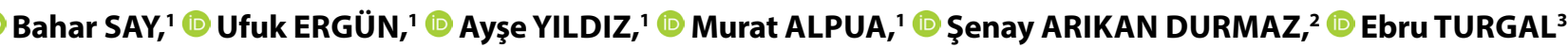

\begin{abstract}
Summary
Objectives: The aim of this study was to test the utility and validity of the full cup test (FCT) to assess the severity of pain in subjects with painful diabetic peripheral neuropathy (PDPN).

Methods: Subjects with diabetic PDPN were enrolled for this prospective, cross-sectional study. Other causes of PDPN and subjects with cognitive impairment were excluded. The diagnosis of neuropathic pain was made using the results of a physical examination and the Douleur Neuropathique 4 questionnaire. Pain severity was assessed with a FCT and a visual analog scale (VAS) administered before and after treatment. The correlation of FCT with VAS was evaluated to examine validity.

Results: A total of 43 (33 female, 10 male) subjects were included. The mean age was $61.9 \pm 8.25$ years and the mean disease duration was 13.02 \pm 7.6 years. Type I diabetes mellitus (DM) was present in 2 (4.7\%) subjects and Type II DM in 41 (95.3\%) subjects. The mean glycated hemoglobin level was $8.9 \pm 1.9 \mathrm{mmol} / \mathrm{mol}$. When the mean VAS and FCT scores were analyzed, the results were $6.7 \pm 2.05$ and $66.35 \pm 23.2$, respectively, pretreatment and $4.6 \pm 2.2$ and $41.36 \pm 23.5$ posttreatment, which were both statistically significant $(p<0.001, p<0.001)$. The mean control period was 23.4 days (min-max: 15-30 days). The VAS and FCT scores in pretreatment and posttreatment demonstrated a high positive correlation $\left(r_{s}=0.86, p<0.001 ; r_{s}=0.843, p<0.001\right)$. Conclusion: The FCT can be useful to detect pain severity in PDPN.
\end{abstract}

Keywords: Diabetes; full cup test; neuropathic pain; pain severity.

\section{Özet}

Amaç: Dolu bardak testinin (DBT) ağrılı diyabetik periferal nöropati (ADPN)'de kullanımını ve geçerliliğini test etmek.

Gereç ve Yöntem: Bu kesitsel ve prospektif çalışmaya ADPN olan olgular alındı. Çalışma popülasyonunda periferal nöropati yapacak diğer nedenler ve kognitif yetmezlik dışlandı. Periferik nöropati tanısı muayene ve Douleur Neuropathique 4 (DN4) anketi kullanılarak gösterildi. Ağrı şiddeti tedavi öncesi ve sonrasında DBT ve Vizüel Analog Skala (VAS) ile değerlendirildi. Geçerlilik için DBT'nin VAS ile korelasyonuna bakıldı.

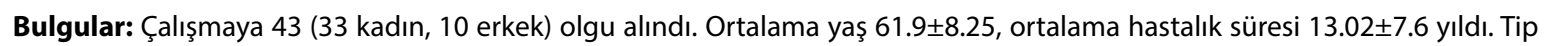
I DM 2 (\%4.7) olguda, Tip II DM 41 (\%95.3) olguda mevcuttu. HbA1c düzeyi ortalama $8.9 \pm 1.9 \mathrm{mmol} / \mathrm{mol}$ 'du. Ağrı şiddetinin değerlendirilmesinde kullanılan VAS ve DBT tedavi öncesi ve sonrası karşılaşıtırıldığında ortalama skorlar tedavi öncesinde $6.7 \pm 2.05,66.35 \pm 23.2$, tedavi sonrasında ise $4.6 \pm 2.2,41.36 \pm 23.5$ bulundu. Sonuçlar istatistiksel olarak anlamlıydı $(p<0.001$, $\mathrm{p}<0.001$ ). Olgularda ortalama kontrol süresi 23.4 (minimum-maksimum: 15-30) gün oldu. Ağrı şiddet ölçeği DBT, tedavi öncesi ve sonrasında VAS ile yüksek korele bulundu $\left(r_{s}=0.86, p<0.001 ; r_{s}=0.843, p<0.001\right)$.

Sonuç: Dolu bardak testi ADPN'de ağrı şiddetini belirlemede kullanışlı olabilir.

Anahtar sözcükler: Diyabet; dolu bardak testi; nöropatik ağrı; ağrı şiddeti.

\section{Introduction}

Pain is one of the most significant and common health problems affecting quality of life. The difficulties associated with the subjective nature of pain have led to varying conclusions in epidemiological studies. Pain comes with a significant economic burden in the form of healthcare costs. ${ }^{[1]}$

Chronic pain is one of the health problems that interfere with the social and emotional status of indi-

\footnotetext{
'Department of Neurology, Kırıkkale University Faculty of Medicine, Kırıkkale, Turkey

${ }^{2}$ Department of Endocrinology and Metabolism, Kırıkkale University, Faculty of Medicine, Kırıkkale, Turkey

${ }^{3}$ Department of Biostatistics, Hitit University, Faculty of Medicine, Çorum, Turkey
}

Submitted (Başvuru tarihi) 11.06.2019 Accepted after revision (Düzeltme sonrası kabul tarihi) 11.10.2019 Available online date (Online yayımlanma tarihi) 23.03.2020

Correspondence: Dr. Bahar Say. Kırıkkale Üniversitesi Tip Fakültesi, Nöroloji Anabilim Dalı, Krrıkale, Turkey.

Phone: +90 - 318 - 4444071 e-mail: drbaharsay@gmail.com

(-) 2020 Turkish Society of Algology 
viduals who have more places in health care costs. Therefore, evaluation and control of chronic pain is important in practice. Assessing the severity of pain is recommended prior to selecting a treatment option and in monitoring response to therapy. The Visual Analogue Scale (VAS) and Numerical Rating Scale (NRS) are easily applicable, intelligible, wellknown and widely accepted for the measurement of pain intensity. ${ }^{[2,3]}$ These numeric scales allow the self-reporting of subjective pain in individuals in different populations. Neuropathic pain which is one of the chronic pains can be observed in diabetic subjects. It is frequently seen as PDPN. In these subjects, it is recommended that neuropathic pain, which is a subjective complaint, be demonstrated and its severity determined and treatment planned. ${ }^{[4]}$

Full cup test is useful for both assessing and differentiating changes in pain. It is simple and non-numeric pain assessment tool. The validity and reliability were reported in different pains. ${ }^{[5,6]}$ This study aimed to investigate the use and validity of FCT in neuropathic pain.

\section{Material and Method}

\section{Subjects}

The consecutive subjects with PDPN were enrolled from neurology and diabetes outpatient clinic between April 2018 and April 2019 to this study. Subjects with PDPN who had pain (burning, shock-like, dysesthesia), negative sensorial symptoms (hypoesthesia, anesthesia, etc) and/or decrease distal sensation, hyporeflexia/areflexia in upper and lower extremities were enrolled. The other reasons of polyneuropathy such as malignancy, thyroid dysfunction, acute or chronic renal failure, other metabolic disorders, chemotherapeutic agents, alcohol abuse and cognitive impairment in subjects (minimental status examination score (MMSE) <24) were excluded.

\section{Methods}

Diagnosis of neuropathic pain was performed by physical examination and DN4 in all subjects with PDPN. Pain severity was detected with VAS and FCT pre-treatment. The treatment of neuropathic pain for each subject was chosen the drug according to the age of the subject, the other diseases and the severity of pain. The second visit was made on the

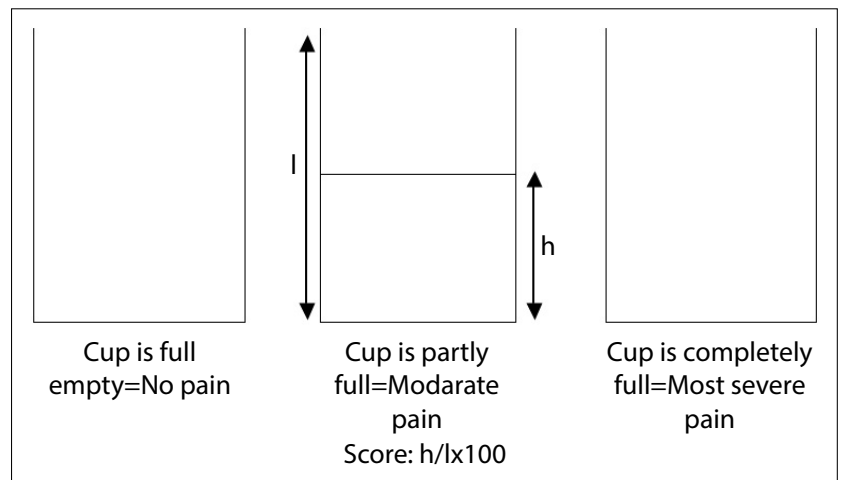

Figure 1. Full cup test.

minimum $15^{\text {th }}$ day and maximum $30^{\text {th }}$ day due to neuropathic pain treatment. The FCT and VAS were applied to all subjects again in post-treatment stage. Evaluations, testing, and data collection were performed by the same neurologist. Changes in FCT and VAS scores with treatment were examined. Correlation between both scales was evaluated.

The study was approved by the institutional local ethics committee and informed consent was waived.

\section{Neuropathic pain questionnaire \\ Douleur neuropathique en 4 (DN4) questionnaire}

The DN4 test is widely utilized to screening of neuropathic pain. It consists of a total ten questions. The first seven questions evaluate subjective symptoms that include pain and sensorial complaints. Clinical signs are examined with the rest three questions. Each positive answer is equal to one point in questionnaire. Scores $\geq 4 / 10$ indicate neuropathic pain. ${ }^{[7]}$

\section{Pain scales}

\section{Visual analog scale (VAS)}

The VAS is a self scale. It is generally that the points between zero and ten are placed in equal distances on a horizontal line in this scale. If no pain equals zero point' and'the most severe pain equals ten points' and you are asked 'which point represents your pain? ${ }^{[8]}$

\section{Full cup test (FCT)}

In FCT, the patient is asked the following question: if you had the worst imaginable pain, this cup would be completely full. If so, please indicate how would the cup be filled by your complaints? The patient draws a level on the cup. The test score is calculated as the height of tha line (cm)/height of cup (cm) $\times 100$ (Fig. 1). A higher score indicates a worse symptom severity. ${ }^{[5]}$ 


\section{Statistical analysis}

Continuous quantitative variables are expressed in terms of mean and standard deviation values, and qualitative variables are expressed in terms of the minimum and maximum values. For testing the quantitative variables independent $t$ test and analysis of variance (ANOVA) were used for normal distributed data; Mann-Whitney U Test and Kruskal-Wallis tests were used for non-normal distributed data. 'Wilcoxon Signed-Ranks test' is used for comparing two variables measured on the same respondents for non-normal distributed data. Pearson correlation test was used for data that were normally distributed. Spearman Correlation test was used for data that were not normally distributed. $P$ values $<0.05$ were considered statistically significant. All data analyses were performed using SPSS 21 package program. (SPSS Inc., Chicago, III, USA). A sample size of 43 achieves $100 \%$ power to detect a mean of paired differences of 2,0 with a known standard deviation of differences of 0,2 and with a significance level (alpha) of 0,05000 using a two-sided Wilcoxon test assuming that the actual distribution is normal. Power analysis was performed by G Power 3. ${ }^{[9]}$

\section{RESULTS}

The study population was composed of 72 subjects with PDPN. Forty-three subjects (33 female, 10 male) completed the follow-up. The characteristics and diabetic treatment modalities of the subjects were given in Table 1. The mean age was $61.9 \pm 8.25$ years and the mean disease duration was $13.02 \pm 7.6$ years. Type I DM was in 2 (4.7\%) subjects, Type II DM in 41 (95.3\%) subjects. HbA1c level was $8.9 \pm 1.9$ (min-max: 6.4-13.8 $\mathrm{mmol} / \mathrm{mol}$ ). In the co-morbidities, hypertension $39.5 \%$, cardiovascular disease (CVD) $20.9 \%$, hyperlipidemia and glaucoma $2.3 \%$ were seen. The mean MMSE score was 29.09 \pm 1.3 . DN4 score was examined and the median score was 5.8 (min-max:5-8). Treatment modalities of neuropathic pain were given in Table 2. Alpha lipoic acid ( 11 subjects, $25 \%$ ) and combine therapy (10 subjects, $23.3 \%$ ) were the most common in treatment modalities.

When the mean VAS and FCT scores were examined, it was $6.7 \pm 2.05,66.35 \pm 23.2$ in pre-treatment and $4.6 \pm 2.2$, $41.36 \pm 23.5$ in post-treatment and the results were statistically significant $(p<0.001, p<0.001)$ (Fig. $2 a$, b). The mean control period was 23.4 (min-max: 15-30) days.
Table 1. The characteristics and treatment modalities of the study group

\begin{tabular}{|c|c|c|}
\hline \multirow[t]{2}{*}{ Variables } & \multicolumn{2}{|c|}{ Subjects $(n=43)$} \\
\hline & $\mathbf{n}$ & $\%$ \\
\hline \multicolumn{3}{|l|}{ Gender } \\
\hline Female & 32 & 74.4 \\
\hline Male & 11 & 25.6 \\
\hline Age (years), mean $\pm S D$ & \multicolumn{2}{|c|}{$61.9 \pm 8.25$} \\
\hline $\begin{array}{l}\text { Duration of diabetes } \\
\text { years, mean } \pm S D\end{array}$ & \multicolumn{2}{|c|}{$13.02 \pm 7.6(1-30)^{*}$} \\
\hline \multicolumn{3}{|l|}{ Diabetes type } \\
\hline Type 1 & 2 & 4.7 \\
\hline Type 2 & 43 & 95.3 \\
\hline $\mathrm{HbA} 1 \mathrm{c}$, mean $\pm \mathrm{SD}$ & \multicolumn{2}{|c|}{$8.9 \pm 1.9$} \\
\hline \multicolumn{3}{|l|}{ Diabetes treatment } \\
\hline $\mathrm{OHA}$ & 21 & 48.8 \\
\hline Insulin & 10 & 23.3 \\
\hline $\mathrm{OHA}+$ insulin & 12 & 27.9 \\
\hline \multicolumn{3}{|l|}{ Other medical conditions } \\
\hline Hypertension & 17 & 39.5 \\
\hline CVD & 9 & 20.9 \\
\hline Hyperlipidemia & 1 & 2.3 \\
\hline Glaucoma & 1 & 2.3 \\
\hline Diabetic foot ulcer & - & - \\
\hline DN4 score, mean & \multicolumn{2}{|c|}{5.8} \\
\hline
\end{tabular}

*: Minimum-maximum; SD: standard deviation; OHA: Oral hypoglysemic agent; CVD: Cardiovascular disease; DN4: Douleur Neuropathique 4.

Table 2. Treatment modalities of neuropathic pain

\begin{tabular}{lcc}
\hline Treatment & n & \% \\
\hline Regulation of blood glucose & 2 & 4.7 \\
Alpha lipoic acid & 11 & 25 \\
Gabapentine & 8 & 18.6 \\
Pregabaline & 3 & 7 \\
Duloxetin & 4 & 9.3 \\
Trazodone hydrochloride & 1 & 2.3 \\
Amitriptyline & 4 & 9.3 \\
Combine therapy & 10 & 23.3 \\
Total & 43 & 100 \\
\hline
\end{tabular}

There was a significant relationship found between the VAS and FCT scores. VAS and FCT scores in pre-treatment and post-treatment showed highest positive correlation $\left(r_{s}=0.86, p<0.001, r_{s}=0.843\right.$ $\mathrm{p}<0.001$ ) (Fig. 3a,b) 

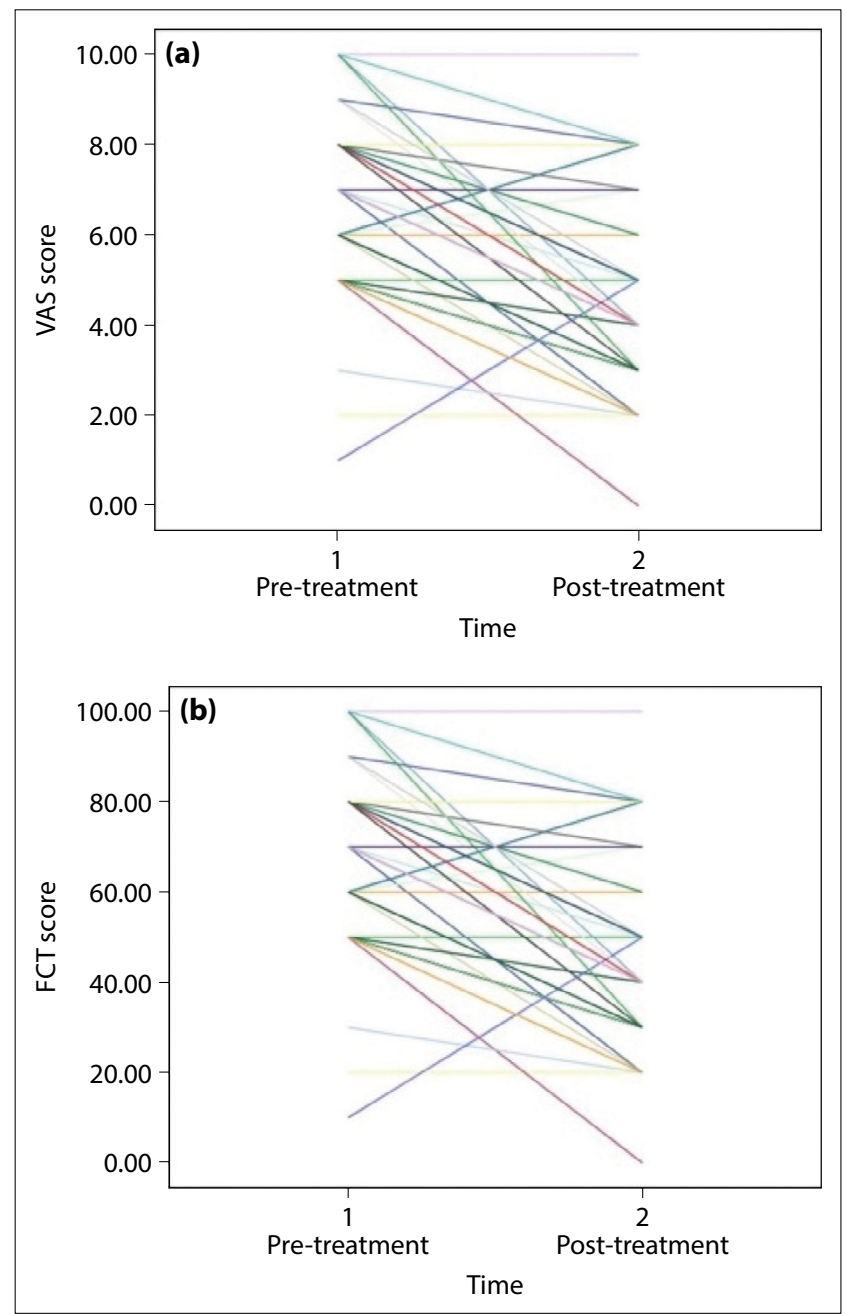

Figure 2. Changes in VAS (a) and FCT (b) scores over time with treatment.

VAS: Visual Analogue Scale; FCT: Full Cup Test.

The usefulness of FCT in subjects with low and more education were examined. 33 (76.7\%) subjects had low education and $10(23.3 \%)$ subjects had education over five years. There was not significant relationship between FCT scores and level of education ( $p=0.133, p=0.630$ ).

\section{DISCUSSION}

The present study found that FCT may be useful and suitable for the assessment of neuropathic pain severity in subjects with PDPN. Positive and significantly correlation was observed between FCT and well known VAS to evaluation of pain.

The measurement of pain intensity/severity is important in the evaluation of pain symptom. Selfreported scales developed for this purpose include the Visual Analogue Scale (VAS), the Numerical Rating Scale (NRS), the Verbal Rating Scale (VRS) and
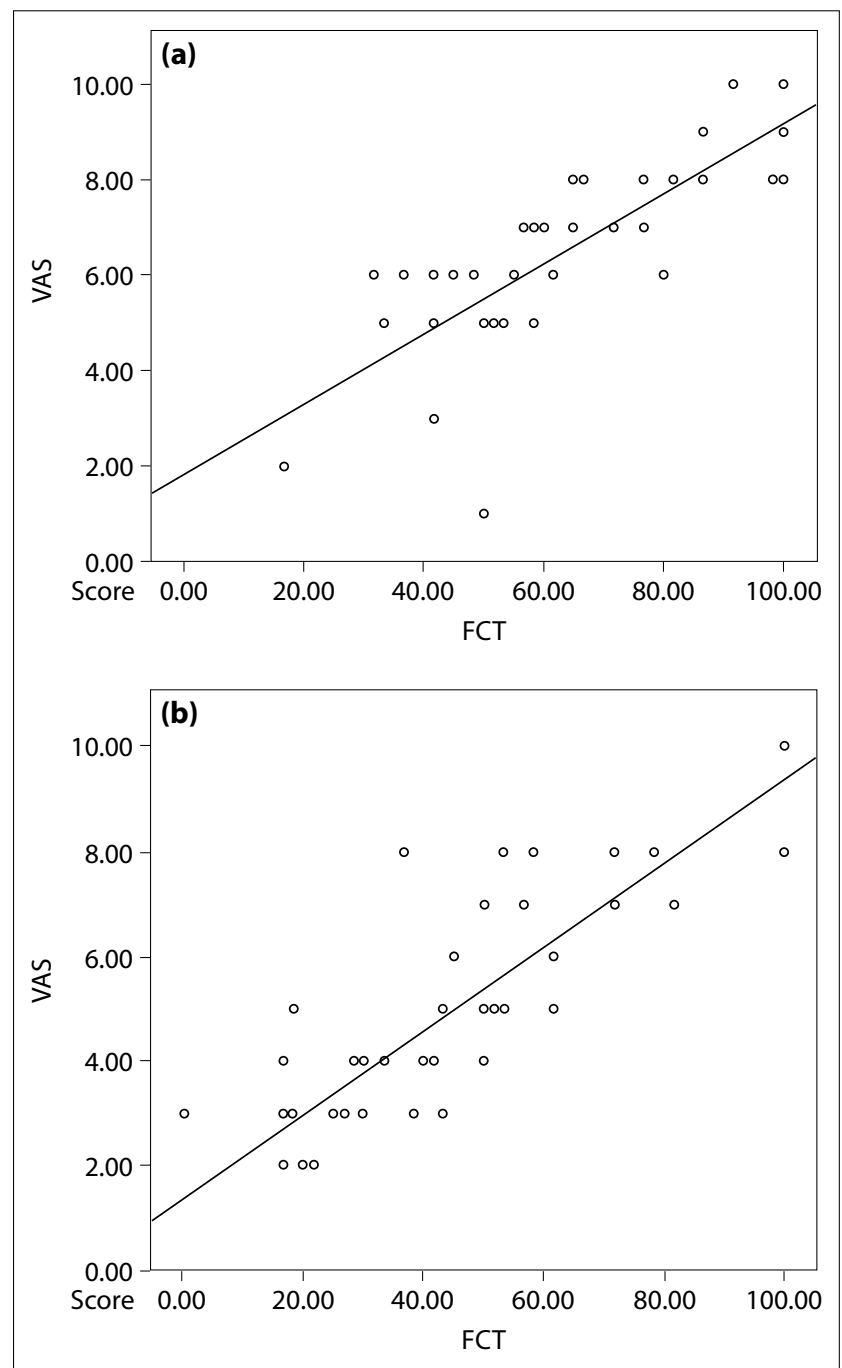

Figure 3. Significant correlation between scores of FCT and VAS in pre-treatment (a) and post-treatment (b).

FCT: Full Cup Test; VAS, Visual Analogue Scale.

the Faces Pain Scale-Revised (FPS-R). ${ }^{[10,11]}$ VAS and NRS are well known scales. These scales having been shown to be sensitive to change. ${ }^{[12]}$ Self-reported scales are recommended especially for the assessment of severity of diabetic neuropathic pain. VAS has been the most widely accepted tool. ${ }^{[13]}$ Brief Pain Inventory (BPI) is also an accepted multidimensional (neuropathic pain and pain severity) pain scale. ${ }^{[14]}$ However, it known that the difficulties depending on the population and the level of educational of the respondents. The subjects may have difficulty in rating the pain they experience, as they consider not only the pain itself but also associated interactions. ${ }^{[15,16]}$ In the present study, easy-and simple, self-reported FCT in PDPN was applied to subjects of both genders and with different levels of education (though mostly low education), and was found to easily identify pain severity. The changes in pain severity with 
treatment were monitored from the FCT scores. In the post-treatment assessment, no change was observed in the scale score of nine subjects, indicating that these subjects did not benefit from therapy. The other subjects were found to have benefited from treatment, based on a decrease in the FCT and VAS scores. These findings support the correlation between FCT and VAS and the validity of this tool in PDPN. In the present study, FCT was applied twice by the same neurologist; however, intra-observer variability could not be evaluated as the severity of neuropathic pain changed with treatment.

Age is a well-known risk factor for PDPN. The incidence of neuropathy and associated pain increases with age. ${ }^{[17]}$ In general, pain is more common in older adults than in young adults, and can be caused by multiple factors. It is recommended that instruments such as those above be applied to measure pain severity in such subjects, along with taking detailed medical history, prior to the preparation of a treatment and follow-up plan. Simple and easy-toadminister pain assessment scales are in common use in daily practice. ${ }^{[18]}$ The mean age of the subjects in the present study was 61 years, and FCT was easily understood in the first and second application by all subjects. When FCT is evaluated taking into account the educational level of the respondent, the concordance between the tests did not differ between those with a low level of educational and those with 5 years of education or longer.

Painful diabetic peripheral neuropathy impairs quality of life in subjects with diabetes, and increases mortality and morbidity with non-traumatic amputations if left unrecognized and untreated. Neuropathic complaints may not be observable with appropriate blood glucose regulation, lifestyle changes, diet, and close follow-up. Pain in the extremities may not be reported by the subjects who relate such symptoms to aging or other processes. ${ }^{[17]}$ For this reason, the presence of neuropathic pain should be inquired in follow-up visits. Many questionnaires have been developed for the assessment of neuropathic pain, which is a subjective symptom. The Douleur neuropathique en 4 questions is one such questionnaire. ${ }^{[19]} \mathrm{An}$ assessment of pain severity after a diagnosis of neuropathic pain is made can contribute greatly to the planning of treatment and to the monitoring of response to therapy. The present study shows the utility of FCT in identifying the severity of neuropathic pain associated with peripheral neuropathy in diabetic subjects. The risk factors preceding the development of neuropathy in diabetic cases are the subject of another study, although prolonged disease duration and poor glycemic control are striking findings among these subjects. Furthermore, cardiovascular disorders are also known to contribute to the development of neuropathy. ${ }^{[13,20,21]}$ The mean disease duration in this study group was 13 years. The $\mathrm{HbA1c}$ level indicates the degree of glycemic control, with a $1 \%$ increase in $\mathrm{HbA} 1 \mathrm{c}$ increasing the risk of diabetic neuropathy developing, although it is also linked to the degree of polyneuropathy. ${ }^{[22-24]}$ The mean $\mathrm{HbA} 1 \mathrm{c}$ level was $8.9 \pm 1.9 \mathrm{mmol} / \mathrm{mol}$ in the present study. Hypertension and cardiovascular diseases were found to be the most common accompanying conditions. In this study, it is thought that neuropathic pain of diabetic subjects with multiple comorbid diseases can be objectively demonstrated by using a pain assessment tool such as FCT and may prevent polytherapy or overdose administration in treatment. Female gender and obesity are other known risk factors for PDPN. ${ }^{[17]}$ The subjects in the present study were not evaluated for obesity, although the high number of female subjects recorded was consistent with the literature. No diabetic foot ulcers were observed in our subjects.

The limitation in the present study is that no evaluation was made of the quality of life, or the presence of sleep and mood disorders, that might correlate with, or be affected by pain. Severe pain in PDPN, when compared to moderate pain, has been shown to be closely related with sleep disorders, anxiety and depression. ${ }^{[25]}$

In summary, it is important to evaluate the severity of pain in terms of treatment and follow-up in neuropathic pain as in the subjects of diabetes. In these subjects, the use of pain assessment tools, which can be applied easily, provides benefit to subjects and clinicians in practice. The FCT can be one of these tools. The utility and validity of it to determine pain severity in PDPN was demonstrated in this study. The usefulness of FCT in subjects with neuropathic pain needs further studies with larger groups. 
Ethics Committee Approval: The Kırıkkale University Clinical Research Ethics Committee granted approval for this study (date: 27.03 .2018 , number: 07/02).

\section{Conflict-of-interest issues regarding the authorship or article: None declared.}

Peer-rewiew: Externally peer-reviewed.

Financial Disclosure: Funding or other financial support: There are not significant competing financial, professional, or personal interests that might have influenced the performance or presentation of the work described in this manuscript.

\section{References}

1. Henschke N, Kamper SJ, Maher CG. The epidemiology and economic consequences of pain. Mayo Clin Proc 2015;90(1):139-47. [CrossRef]

2. Breivik $H$, Borchgrevink PC, Allen SM, Rosseland LA, Romundstad L, Hals EK, et al. Assessment of pain. Br J Anaesth 2008;101(1):17-24. [CrossRef]

3. Fillingim RB, Loeser JD, Baron R, Edwards RR. Assessment of Chronic Pain: Domains, Methods, and Mechanisms. J Pain 2016;17(9 Suppl):T10-20. [CrossRef]

4. Paisley P, Serpell M. Improving pain control in diabetic neuropathy. Practitioner 2017;261(1802):23-6.

5. Ergün U, Say B, Ozer G, Yildirim O, Kocatürk O, Konar D, et al. Trial of a new pain assessment tool in patients with low education: the full cup test. Int J Clin Pract 2007;61(10):16926. [CrossRef]

6. Al-Samman AA, Al-Nuaime OS, Othma HA. Validity and Reliability of Full Cup Test in Pain Evaluation after Dental Surgery: A Comparison with Four Pain-Rating Scales in a Sample of Iraqi Patients. Journal of Oral and Dental Research 2016;1(1):2-7. [CrossRef]

7. Jones RC $3^{\text {rd }}$, Backonja MM. Review of neuropathic pain screening and assessment tools. Curr Pain Headache Rep 2013;17(9):363. [CrossRef]

8. Lund I, Lundeberg T. Aspects of pain, its assessment and evaluation from an acupuncture perspective. Acupunct Med 2006;24(3):109-17. [CrossRef]

9. Faul F, Erdfelder E, Lang AG, Buchner A. G*Power 3: a flexible statistical power analysis program for the social, behavioral, and biomedical sciences. Behav Res Methods 2007;39(2):175-91. [CrossRef]

10. Jensen MP, Karoly P, Braver S. The measurement of clinical pain intensity: a comparison of six methods. Pain 1986;27(1):117-26. [CrossRef]

11. Jensen $M$, Karoly P. Self-report scales and procedures for assessing pain in adults. In: Turk DC, Melzack R, editors. Handbook of pain assessment. $2^{\text {nd }}$ ed. New York: Guilford Press; 1992. p. 135-51.
12. Williamson A, Hoggart B. Pain: a review of three commonly used pain rating scales. J Clin Nurs 2005;14(7):798804. [CrossRef]

13. Tesfaye S, Boulton AJ, Dyck PJ, Freeman R, Horowitz M, Kempler $\mathrm{P}$, et al; Toronto Diabetic Neuropathy Expert Group. Diabetic neuropathies: update on definitions, diagnostic criteria, estimation of severity, and treatments. Diabetes Care 2010;33(10):2285-93. [CrossRef]

14. Tan G, Jensen MP, Thornby Jl, Shanti BF. Validation of the Brief Pain Inventory for chronic nonmalignant pain. J Pain 2004;5(2):133-7. [CrossRef]

15. Pathak A, Sharma S, Jensen MP. The utility and validity of pain intensity rating scales for use in developing countries. Pain Rep 2018;3(5):e672. [CrossRef]

16. Serlin RC, Mendoza TR, Nakamura Y, Edwards KR, Cleeland CS. When is cancer pain mild, moderate or severe? Grading pain severity by its interference with function. Pain 1995;61(2):277-84. [CrossRef]

17. Sloan G, Shillo P, Selvarajah D, Wu J, Wilkinson ID, Tracey I, et al. A new look at painful diabetic neuropathy. Diabetes Res Clin Pract 2018;144:177-91. [CrossRef]

18. Herr K. Pain assessment strategies in older patients. J Pain 2011;12(3 Suppl 1):S3-S13. [CrossRef]

19. Bennett MI, Attal N, Backonja MM, Baron R, Bouhassira D, Freynhagen $\mathrm{R}$, et al. Using screening tools to identify neuropathic pain. Pain 2007;127(3):199-203. [CrossRef]

20. Oguejiofor OC, Odenigbo CU, Oguejiofor CB. Evaluation of the effect of duration of diabetes mellitus on peripheral neuropathy using the United Kingdom screening test scoring system, bio-thesiometry and aesthesiometry. Niger J Clin Pract 2010;13(3):240-7.

21. Young MJ, Boulton AJ, MacLeod AF, Williams DR, Sonksen $\mathrm{PH}$. A multicentre study of the prevalence of diabetic peripheral neuropathy in the United Kingdom hospital clinic population. Diabetologia 1993;36(2):150-4. [CrossRef]

22. Stratton IM, Adler Al, Neil HA, Matthews DR, Manley SE, Cull CA, et al. Association of glycaemia with macrovascular and microvascular complications of type 2 diabetes (UKPDS 35): prospective observational study. BMJ 2000;321(7258):405-12. [CrossRef]

23. Lai YR, Chiu WC, Huang CC, Tsai NW, Wang HC, Lin WC, et al. $\mathrm{HbA1C}$ Variability Is Strongly Associated With the Severity of Peripheral Neuropathy in Patients With Type 2 Diabetes. Front Neurosci 2019;13:90. [CrossRef]

24. Su JB, Zhao LH, Zhang XL, Cai HL, Huang HY, Xu F, et al. $\mathrm{HbA} 1 \mathrm{c}$ variability and diabetic peripheral neuropathy in type 2 diabetic patients. Cardiovasc Diabetol 2018;17(1):47.

25. Gore M, Brandenburg NA, Dukes E, Hoffman DL, Tai KS, Stacey B. Pain severity in diabetic peripheral neuropathy is associated with patient functioning, symptom levels of anxiety and depression, and sleep. J Pain Symptom Manage 2005;30(4):374-85. [CrossRef] 